\title{
T Regulatory Cell Levels Decrease in People Infected With Schistosoma mansoni on Effective Treatment
}

\author{
Kanji Watanabe, Pauline N. M. Mwinzi, Carla L. Black, Erick M. O. Muok, Diana M. S. Karanja, W. Evan Secor, and \\ Daniel G. Colley* \\ Center for Tropical and Emerging Global Diseases, and the Department of Microbiology, University of Georgia, Athens, Georgia; \\ Institute of Tropical Medicine, Nagasaki University (NEKKEN), Nagasaki, Japan; Kenya Medical Research Institute, Centre for \\ Global Health Research, Kisumu, Kenya; Centers for Disease Control and Prevention, Division of Parasitic Diseases, \\ Atlanta, Georgia
}

\begin{abstract}
Schistosomiasis mansoni is usually a chronic infection that leads to long-term, systemic exposure to schistosome antigens. Experimental Schistosoma mansoni infection is associated with immunoregulatory mechanisms, including $\mathrm{T}$ regulatory cells (Treg) that may help control morbidity and dampen resistance to re-infection. We now show that some schistosomiasis mansoni patients have high proportions of $\mathrm{CD}^{+} / \mathrm{CD} 4^{+} / \mathrm{CD} 25^{\text {high }}$ Treg. On effective treatment with praziquantel, these high Treg percentages decrease, and fewer of the remaining Treg express CD45RO. The proportion of Treg in $S$. mansoni-infected patients is inversely related to their percentage of activated, putative effector

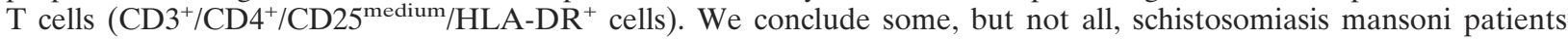
develop high percentages of circulating Treg, and effective treatment both decreases the levels of these cells and changes their phenotypes, possibly because of the removal of constant exposure to antigens from intravascular, egg-producing adult worms.
\end{abstract}

\section{INTRODUCTION}

Schistosoma mansoni is a parasitic trematode that resides in the mesenteric veins of its human host. After several weeks of development, female adult schistosomes begin to lay eggs that have been fertilized by the male worm. The eggs are either excreted in the feces, to continue the life cycle, or become impacted in the liver where they induce granuloma formation that may lead to periportal fibrosis and severe morbidity. ${ }^{1,2}$ The life span of adult $S$. mansoni worms is several years, and infected humans are often repeatedly infected. ${ }^{3-5}$ Thus, patients in endemic areas are often exposed to long-term, continuous systemic exposure to egg and worm antigens.

During chronic infection, egg and worm antigens primarily provoke Th2 responses such as IgE and interleukin (IL)-5, some of which have been shown to correlate with resistance to re-infection. ${ }^{6-9}$ Our group recently confirmed that eosinophilia correlates with resistance to re-infection. ${ }^{10}$ However, Th2 responses also have been associated with morbidity, and in some studies, Th1 responses have been associated with resistance to re-infection. ${ }^{11}$

Although many situations may lead to host resistance to re-infection, one such condition seems to be treatment with praziquantel (PZQ). Immune responses that correlate with resistance to re-infection, such as increased $\mathrm{IgE}$ levels, decreased IgG4 levels, and changes in antigen recognition patterns are altered coincident with PZQ treatment. ${ }^{6-9,12-15}$ Furthermore, schistosome antigen-specific changes in IL-4, IL-5, IL-10, and IL-13 responses have been observed on treatment. ${ }^{14,16}$ It is hypothesized that persons who are treated with PZQ are exposed to bursts of schistosome antigens that may alter immune responses and eventually increase resistance to re-infection. ${ }^{17,18}$

Natural T regulatory cells (Treg) ${ }^{19-21}$ have a major role in the control of immune responses in multiple settings, includ-

\footnotetext{
* Address correspondence to Daniel G. Colley, Center for Tropical and Emerging Global Diseases, Coverdell Center, Room 145, University of Georgia, 500 D.W. Brooks Drive, Athens, GA 30602-3799. E-mail: dcolley@uga.edu
}

ing thymic development, autoimmunity, atopic allergy, transplantation, and infectious diseases. ${ }^{22,23}$ In human paracocidiodomycosis, $\mathrm{CD} 4{ }^{+} \mathrm{CD} 25^{+}$cells (defined as Treg) accumulate in characteristic granulomatous lesions and exert strong suppressive activity on effector cells, implying that Treg might contribute to the regulation of these lesions. ${ }^{23}$ In murine experimental schistosomiasis, Treg responses control both Th1 and Th2 responses in an IL-10-independent manner ${ }^{24,25}$ and are associated with regulation of granuloma formation in chronic infections. ${ }^{26}$ To our knowledge, no one has yet reported on Treg in humans with schistosomiasis mansoni.

For a number of years, our group has been studying cohorts of adult men who are occupationally exposed to $S$. mansoni. ${ }^{10,27-30}$ The initial cohort was men who washed cars in Lake Victoria near Kisumu, Kenya. More recently, we also studied men who harvest sand from the bottom of Lake Victoria. Up to one third of these individuals are co-infected with HIV $-1 .^{30}$ In a previous longitudinal study, we found that some occupationally exposed men are relatively resistant to reinfection or develop resistance to re-infection after multiple treatments and re-infections, whereas others remain highly susceptible to re-infection. ${ }^{28}$ In this study, we studied the percentages of Treg (defined herein as $\mathrm{CD} 3^{+} / \mathrm{CD} 4^{+} / \mathrm{CD} 25^{\text {high }}$ cells $)^{20}$ in schistosome-infected patients and those cured of their infections. We found that some patients exhibit high percentages of Treg and that these percentages decline after effective treatment with praziquantel (PZQ). Furthermore, the phenotypes of Treg change upon treatment, with fewer Treg expressing CD45RO, a marker associated with T-cell memory and suppressive activity.

\section{MATERIALS AND METHODS}

Study participants. This study was done near Kisumu in western Kenya. Kisumu is located on the shores of Lake Victoria. The existence of S. mansoni-infected Biomphalaria sudanica snails has been confirmed (unpublished data) in the area around the exposure site. The study participants (age, 18-64 years; mean, 28.8 years) were sand harvesters and were 
thus occupationally exposed to schistosome transmission as they harvested and unloaded sand from the bottom of Lake Victoria while standing in the water. This study was performed from June 2005 to September 2006. Some of the studies were cross-sectional, whereas a subgroup of 12 patients was followed over time, allowing for a follow-up observation period after PZQ treatment and documented cure.

This study was approved by the Institutional Review Boards of the University of Georgia and the Centers for Diseases Control and Prevention, the Scientific Steering Committee of the Kenya Medical Research Institute, and the National Ethics Review Board of Kenya. After obtaining informed consent and enrolling the participants, we examined their stools for $S$.mansoni eggs and for other helminth ova by the modified Kato-Katz method (Vestergaard-Frandsen, Denmark). The participants who were positive for S. mansoni were treated with $40 \mathrm{mg} / \mathrm{kg}$ PZQ; men positive for other helminth ova were treated with $400 \mathrm{mg}$ albendazole.

CD4/CD8 cell counts and whole blood differential count were determined by FACScount and Coulter Counter analysis, as previously reported. ${ }^{28}$ After confirming that the participants had received HIV-1 counseling and testing through the Kenyan Ministry of Health Volunteer Counseling and Testing service, independent HIV-1 screening was performed on the patients' plasma samples in our laboratory (Abbott Determine HIV 1/2; Abbott Japan Co., Minato-Ku, Japan), and confirmatory tests were done on positives (Unigold; Trinity Biotech, Bray, Ireland).

Previously untreated, egg-positive patients were separated into two groups (based on their HIV-1 status), and their data were analyzed separately (Table 1 ). The mean eggs per gram feces (EPG) of HIV-seropositive patients $\left(\mathrm{HIV}^{+}\right)$was lower $(P<0.05)$ than that of HIV seronegative (HIV-) patients (Table 1), consistent with our previous findings in occupationally exposed adult men with exceptionally high egg counts. ${ }^{30}$ As expected, the mean $\mathrm{CD}^{+}$cell count was lower and the $\mathrm{CD}^{+}$cell count higher in the $S$. mansoni-infected patients who were co-infected with HIV-1 than in those without HIV-1 infection (Table 1).

Cell surface staining and flowcytometric analysis. Blood was collected by venipuncture into EDTA-coated glass tubes (BD Vacutainer System, Franklin Lakes, NJ). To identify Treg in peripheral blood, anti-CD3 (fluorescein isothiocyanate [FITC] or allophycocyanin [APC] conjugated, clone: UCHT1; e-Bioscience, San Diego, CA), anti-CD4 (FITC or PerCP conjugated, clone: OKT-4; e-Bioscience), and antiCD25 (PE conjugated, clone:BC96; e-Bioscience) were used. Because anti-FOXP3 antibodies were not commercially available at the beginning of this study, we defined Treg cells as the $\mathrm{CD}^{+} / \mathrm{CD}^{+} / \mathrm{CD} 25^{\text {high }}$ population. ${ }^{31-37}$ Gating to separate

TABLE 1

Quantification of S. mansoni eggs and CD4 and CD8 cells in untreated schistosomiasis patients by HIV status

\begin{tabular}{lcccc}
\hline & & \multicolumn{3}{c}{ Mean value \pm SD } \\
\cline { 3 - 5 } Patient group & No. of patients & EPG* & CD4 count & CD8 count \\
\hline HIV $(-) \dagger$ & 48 & $1,050(1,452)$ & $658(248) \ddagger$ & $489(298) \neq$ \\
HIV $(+) \dagger$ & 7 & $330(527) \S$ & $303(185)$ & $934(447)$ \\
\hline
\end{tabular}

* Schistosoma mansoni EPG.

$\dagger$ HIV(-), HIV-1 seronegative; HIV(+), HIV-1 seropositive.

$\doteqdot P<0.01$ compared with $\mathrm{HIV}(+)$ group.

$\S P<0.05$ compared with HIV (-) group.
CD25neg cells from CD25medium cells was based on fluorescence minus one (FMO)-stained samples. ${ }^{38}$ The gating used to distinguish $\mathrm{CD} 25^{\text {high }}$ from $\mathrm{CD} 25^{\text {medium }}$ cells was determined by examining the CD4/CD25 dot plots from all patients studied and setting thresholds that most often differentiated these subpopulations $\left(\mathrm{CD} 25^{\text {low }}, \mathrm{CD} 25^{\text {medium }}\right.$, $\left.\mathrm{CD} 25^{\text {high }}\right) .^{20,32}$ These thresholds (Figure 1) were determined before any phenotypic analyses, were used for all analyses in this study and are based on those used throughout the literature. ${ }^{32-37}$ To examine phenotypic subsets of Treg, the following antibodies were used: anti-PD-1 (CD279; FITC conjugated, clone: MIH4; e-Bioscience), anti-CD152 (APC conjugated, clone: BNI3; BD Pharmingen, San Diego, CA), antiCD45RO (APC conjugated, clone:UCHL1; BD Pharmingen), and anti-HLA-DR (APC conjugated, clone: LN3; e-Bioscience). FMO-stained samples were used to separate positive from all negative populations. ${ }^{38}$

Statistical analysis. Statistical analyses were performed using GraphPad PRISM version 3.0 for Windows (Graph Pad Software, San Diego, CA) and Microsoft Excel. The MannWhitney $U$ test was used for nonparametric group comparisons. Wilcoxon matched pairs signed rank test was used to analyze the changes of Treg percentages and phenotypes before and after PZQ treatment. Spearman rank test was used to examine possible correlations between EPG and Treg percentages and the percentages of Treg versus activated $\mathrm{T}$ effector cells. $P$ values of 0.05 were considered to indicate statistical significance.

\section{RESULTS}

Proportion of Treg in schistosome-infected patients. Schistosome-infected patients who had not been treated previously and who were HIV-1 seronegative $(N=48)$ had a mean percentage of Treg $\left(\mathrm{CD}^{+} / \mathrm{CD}^{+} / \mathrm{CD} 25^{\text {high }}\right.$ cells) of $4.7 \%$ $(\mathrm{SD}=3.5)$. For patients who had not been treated with PZQ before but were HIV-1 seropositive $(N=7)$, it was $5.5 \%$ $(\mathrm{SD}=3.7)$. Because there was no significant difference in the $\%$ Treg between these HIV $-1\left(^{+}\right)$and HIV-1(-) groups, they are plotted together in Figure 2. Among these egg-positive patients, there were 17 patients (31\%) who had what we considered high percentages $(5 \%-10 \%)$ of Treg and $5(9 \%)$ who had very high Treg percentages (>10\%; Figure 2). Average percentages of circulating $\mathrm{CD} 4^{+} / \mathrm{CD} 25^{\text {high }}$ Treg in normal individuals are $1 \%-3 \% .^{20,39}$ Thus, $40 \%$ of patients with patent $S$. mansoni infections exhibited high or very high percentages of circulating Treg.

Changes of Treg percentages and phenotypes after PZQ treatment. To examine the effect of treatment on Treg populations in persons with schistosomiasis, a subgroup of patients was longitudinally followed before and after treatment with PZQ. The time between the pre-treatment evaluation and the re-evaluation on cure ranged from 8 to 14 months (mean $\pm \mathrm{SD} ; 9.4 \pm 1.8$ months). These studies were performed only on individuals who were actively infected at the first examination, had not been treated previously, were cured on treatment (went to zero EPG and remained negative until at least the time of the second phenotypic analysis), and were HIV-1(-) (Figure 3). Before treatment, the mean percentage of Treg was $6.1 \%(\mathrm{SD}=4.2)$; this value decreased to $3.7 \%(\mathrm{SD}=1.2)$ after treatment $(P=0.05)$, showing a significant impact of effective treatment. PD-1 (CD279) was expressed on $12.1 \%$ Treg $(\mathrm{SD}=7.4)$ before treatment, and this 


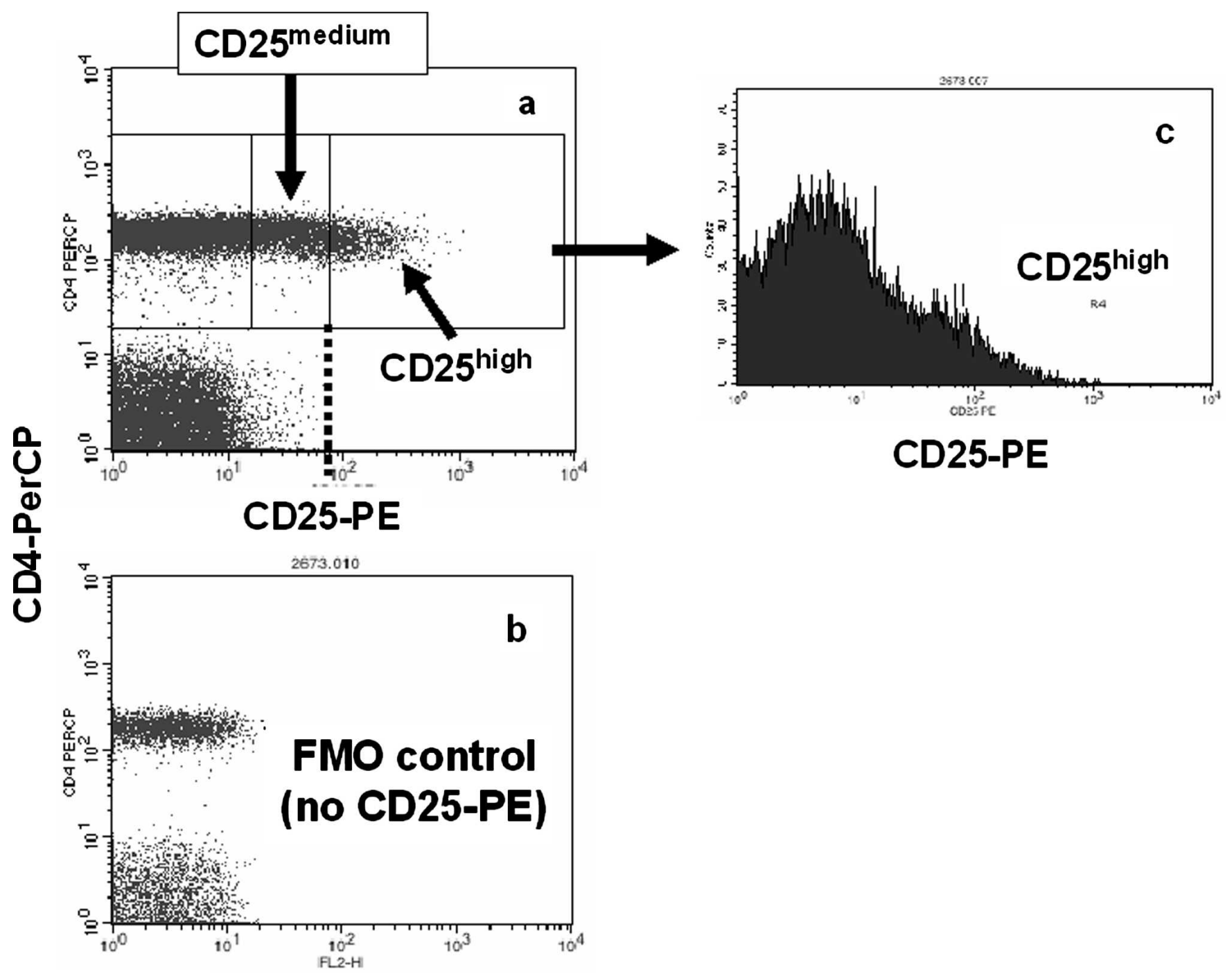

FIGURE 1. Flow cytometry analysis of whole blood cells stained with anti-CD3, anti-CD4, and anti-CD25 was used to define $\mathrm{CD} 3^{+} \mathrm{CD} 4^{+} \mathrm{CD} 25^{\text {high }}$ cells. A, $\mathrm{CD}^{+} / \mathrm{CD}^{+}$lymphocytes were gated and analyzed for positive $\mathrm{CD} 25$ expression using a threshold $(\mathbf{B})$ based on the fluorescence minus one (FMO) "no CD25-PE" controls. ${ }^{38}$ After examination of the scatter plots of all patients, a threshold was set between $\mathrm{CD} 25^{\text {medium }}$ and $\mathrm{CD} 25^{\text {high }}$ cells [dotted line in $\mathbf{A}$ ]. This threshold, and that provided by the FMO controls, was then used throughout for all analyses. C, Histogram of CD25-PE spectrum showing where the CD25 $5^{\text {high }}$ gate was set throughout.

increased, but not significantly, to $18.9 \%(\mathrm{SD}=7.6)$ on cure (Figure 3B; $P=0.07)$. CD45RO was expressed on $85.9 \%$ of Treg before treatment $(\mathrm{SD}=6.5)$ but occurred on only $65.9 \%(\mathrm{SD}=20.4)$ of Treg after treatment and cure $(P=$ 0.002; Figure 3C). Thus, Treg expression of CD45RO, which is often associated with T-cell memory, was significantly decreased after treatment. Multiple studies have shown that $\sim 85 \%$ of Treg in most human subjects express CD45RO. ${ }^{20,39-41}$ In cross-sectional studies, $79 \%$ of Treg cells in our HIV $(-)$ patients $(N=48)$ expressed CD45RO. We also tested cells from most of our HIV(-) patients for expression of HLA-DR by Treg, which is indicative of T-cell activation in humans, ${ }^{20,42,43}$ and found that $23 \%$ of Treg were $\mathrm{HLA}_{-} \mathrm{DR}^{+}(N=36)$. In addition, we tried to assess the expression of CD152 (CTLA-4) on Treg, but these assays failed to detect significant surface membrane expression of this marker (usually $<1 \%$ Treg were surface-CD $152^{+}$, data not shown).
Treg and the intensity of infection. We analyzed the Treg proportions in the peripheral blood of patients before treatment with PZQ who were HIV-1(-) $(N=48)$ in relationship to the intensity of infection, based on the number of EPG (Figure 4). There was no statistically significant correlation between the generally high intensities of infection in this cohort (Table 1; Figure 4) and the percentages of Treg in the circulation $(P=0.19)$.

Relationship of Treg percentages to peripheral blood eosinophilia and activated $\mathrm{CD}^{+} \mathrm{CD}^{\mathrm{medium}} \mathrm{T}$ cells. These western Kenyan patients have elevated peripheral blood eosinophilia that correlates with increased resistance to reinfection, ${ }^{10}$ consistent with earlier studies that human eosinophils may be effector cells against schistosomes. ${ }^{44,45}$ Therefore, we examined the relationship between the percentages of Treg and eosinophilia. We did not, however, find any correlation between these two cell populations in the peripheral blood of our patients $(N=47 ; r=0.02 ; P=0.91)$. 


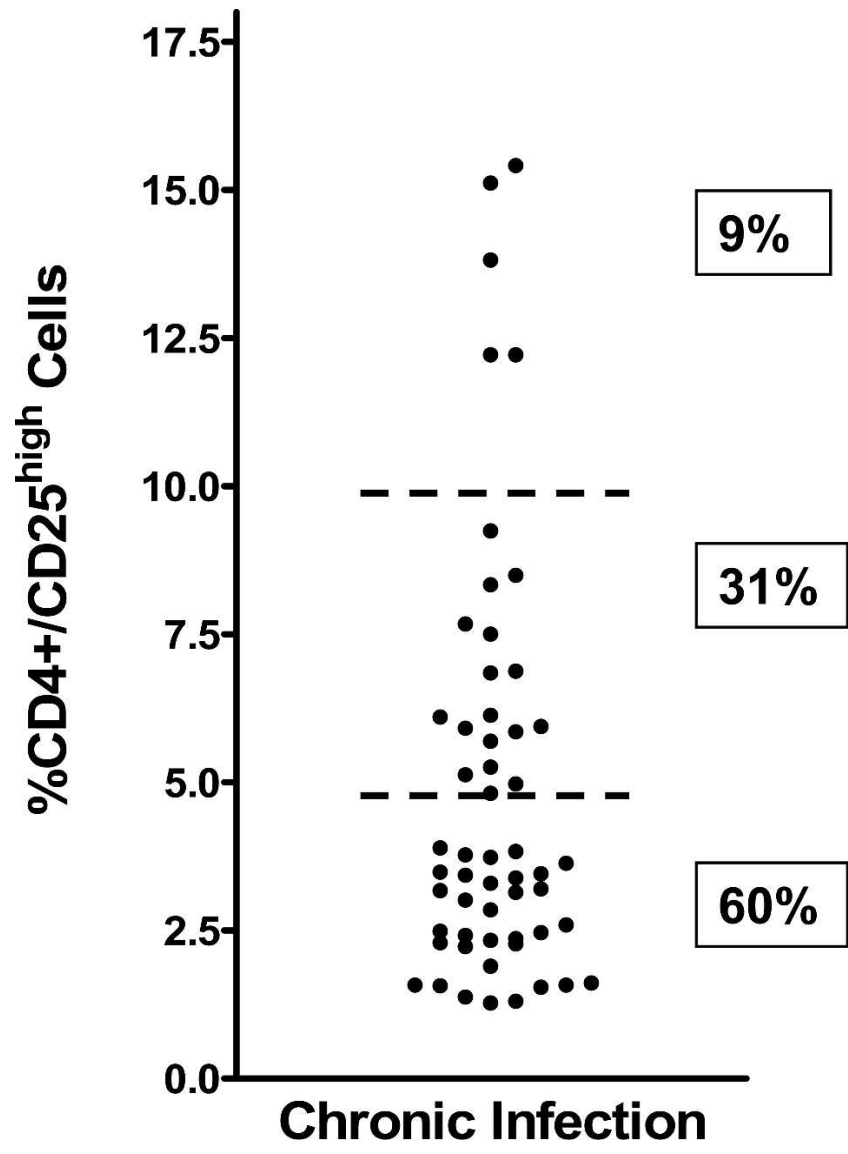

Figure 2. Percentages of Treg $\left(\mathrm{CD} 3^{+} \mathrm{CD} 4^{+} \mathrm{CD} 25^{\text {high }}\right.$ cells $)$ in the peripheral blood of untreated, schistosome-infected patients. Horizontal dashed bars indicate stratification levels of patients with $<5 \%$, $5 \%-10 \%$, or $>10 \%$ Treg in their circulation.

By using CD4/CD25 gating strategies based on FMO and examining all patient data, we identified both the Treg population (CD25 $\left.5^{\text {high }}\right)$ and an activated, putative effector T-cell population (CD25 $\left.5^{\text {medium }}\right){ }^{39}$ When the proportions of these two $\mathrm{CD}^{+}$populations were further analyzed by comparing the percentage of Treg against the percentage of presumed effector $\mathrm{T}$ cells that were activated $\left(\mathrm{CD} 4^{+} / \mathrm{CD} 25^{\text {medium }}\right.$, HLA-DR ${ }^{+}$), we found a statistically significant negative correlation between these two populations of $\mathrm{T}$ lymphocytes (Figure 5). Thus, those patients who had higher percentages of Treg had lower percentages of activated effector T cells $(N=35 ; r=-0.37 ; P=0.03)$. This relationship was not found when Treg were analyzed against effector T-cell populations (CD4 $\left.{ }^{+} / \mathrm{CD} 25^{\text {medium }}\right)$ that were not activated (i.e., did not express HLA-DR; data not shown). The reciprocal relationship of increased Treg and decreased activated $\mathrm{T}$ effector cells needs further study at the functional level in this chronic antigen exposure condition.

\section{DISCUSSION}

Accumulating data on naturally occurring Treg indicate that they are involved in immune regulation of various conditions such as autoimmune diseases, graft organ transplantation, and infectious diseases. ${ }^{22,46}$ In infectious diseases, Treg may be induced in antigen-specific manner and may suppress tissue destruction resulting from immune responses. ${ }^{23}$ In experimental schistosomiasis and the schistosome egg injection model, Treg is reported to control both Th1 and Th2 aspects of the immune response. ${ }^{25}$ In this study, we examined Treg in schistosome-infected patients and analyzed them before and after effective treatment with the antischistosomal drug PZQ. We found that the mean percentage of Treg in the peripheral blood of our patients was $\sim 5 \%$, which is more than double levels reported in the literature for persons who do not have schistosomiasis. ${ }^{20,39}$ Paired data analysis showed a statistically significant decrease in Treg percentages on treatment and cure of schistosomiasis (Figure 3). We hypothesized that the removal of chronic, systemic exposure to schistosome antigens through PZQ treatment led to the decrease. In contrast, Treg percentages did not correlate with intensity of infection (Figure 4). However, this analysis may be somewhat confounded by the extremely high intensities of infection observed in the occupationally exposed cohort studied.

PD-1 (CD279) is a surface receptor that, along with one of its ligands PD-L1, is involved in regulating T-cell activation. ${ }^{47,48}$ In chronic viral infections, this pathway can inhibit CD8 T-cell responses. ${ }^{49,50}$ PD-L1 ligation of PD-1 can also induce apoptosis of $\mathrm{T}$ cells. ${ }^{51}$ In schistosome infection, inhibition of the PD-1/PD-L1 pathway restores the suppressed response of $\mathrm{T}$ cells to adult worm antigen. ${ }^{52}$ In addition, mice with severe schistosome-related morbidity have fewer $\mathrm{T}$ cells that express PD-1 than mice with less severe disease. ${ }^{53}$ In this human study, PD-1 was expressed on a mean of $14.5 \%$ of Treg cells in the cross-sectional, untreated HIV-1(-) patients, (data not shown), and on $12.1 \%$ of the Treg of the 12 patient subgroup before treatment. On treatment and cure, whereas the mean percentage of Treg went down (Figure 3A), the percentage of the Treg that expressed PD-1 increased in 8 of 12 men (Figure 3B). Where it occurred, increased PD-1 expression by Treg may have contributed to the decrease in Treg percentages through the induction of apoptosis through PD-L1 ligation. ${ }^{51}$

A mean of $79 \%$ of the circulating Treg of all untreated, HIV-1(-) patients were positive for CD45RO, a memory cell marker consistently expressed on a very high percentage of Treg. ${ }^{20,39-41}$ Among CD $4^{+} / \mathrm{CD} 25^{+} \mathrm{T}$ cells, CD $45 \mathrm{RO}^{+}$cells have a suppressive phenotype. ${ }^{54}$ Interestingly, in the 12 patients followed before treatment and after cure, a significant decrease was observed in the percentage of Treg that express CD45RO (Figure 3C). This could indicate that not only did the overall percentage of Treg decrease on cure, but those that remain after treatment and cure were less suppressive than those present before treatment. ${ }^{54}$ However, because no functional studies were done in this investigation, it is impossible to evaluate this hypothesis at this time.

We observed an intriguing relationship between $\mathrm{CD}^{+} /$ $\mathrm{CD} 4^{+} / \mathrm{CD} 25^{\text {high }}$ Treg cells and $\mathrm{CD}^{+} / \mathrm{CD} 4^{+} / \mathrm{CD} 25^{\text {medium}} /$ HLA-DR ${ }^{+}$activated, putative effector $\mathrm{T}$ cells in the circulation of actively infected schistosomiasis mansoni patients (Figure 5). Our data indicated a reciprocal relationship between these two populations of cells. Although this is only a correlation, and not necessarily a cause and effect relationship, it could mean that a higher proportion of circulating Treg leads to a lower proportion of activated effector $\mathrm{T}$ cells. This relationship did not exist if the $\mathrm{CD} 4^{+} / \mathrm{CD} 25^{\text {medium }} \mathrm{T}$ cells were not activated (i.e., did not co-express HLA-DR). Unfortunately, it was not possible to examine this relationship 
(A)

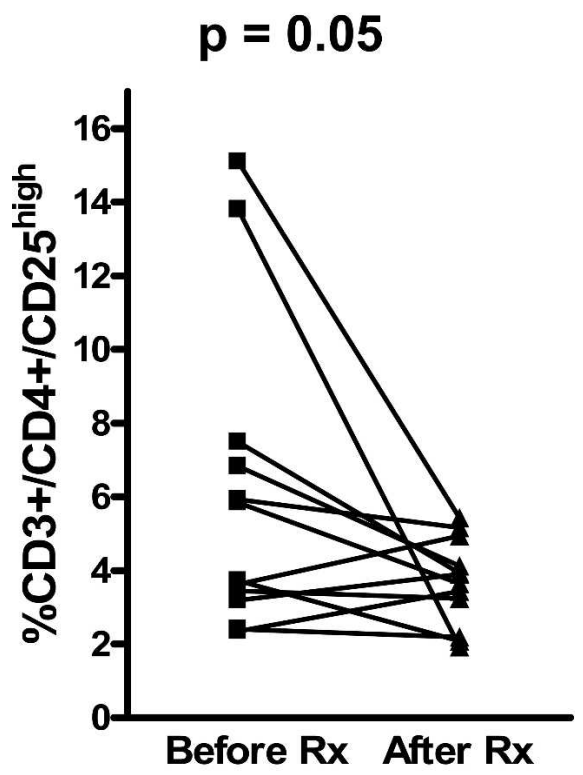

(B)

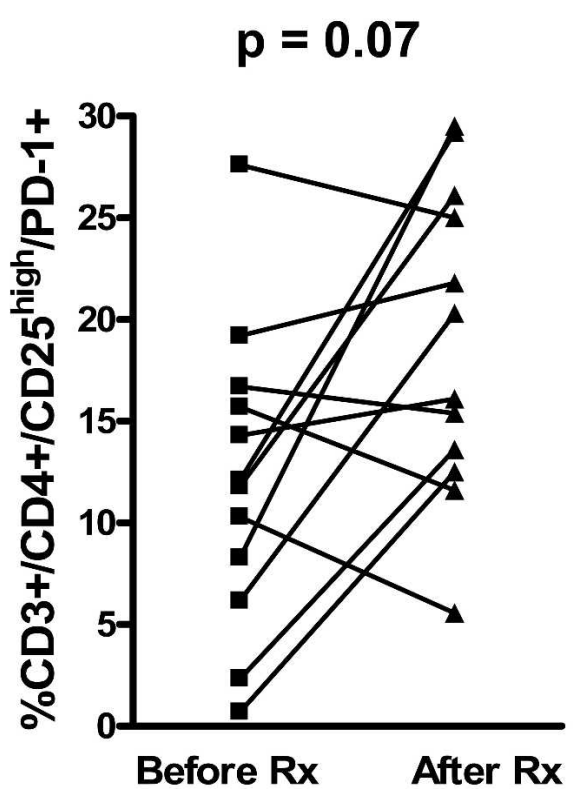

(C)

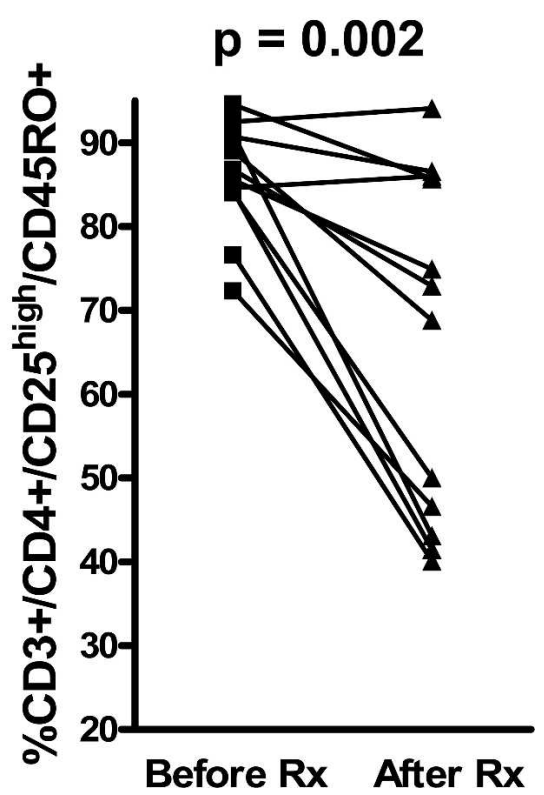

Figure 3. Changes in levels of Treg and Treg subsets in 12 patients before treatment and after treatment and cure: (A) Treg; (B) PD-1 expression by Treg; (C) CD45RO expression by Treg.

after treatment and cure because of an inadvertent resetting of the FL4 gain in the middle of the study to a point that discrimination of HLA-DR positivity could not be determined. In this descriptive study, we did not attempt to examine the functional role of these populations against another, because this would likely require a level of fine cell sorting that is not available to us in the Kisumu laboratory. In contrast to this potential regulatory relationship between Treg and activated effector CD4 $\mathrm{T}$ cells, we did not find any relationship between the percentages of circulating Treg and peripheral blood eosinophilia.

In this study, we used a $\mathrm{CD} 25^{\text {high }}$ gate on $\mathrm{CD} 3^{+} / \mathrm{CD}^{+} \mathrm{T}$ cells to identify Treg because anti-FOXP3 antibodies were not commercially available when we began the study. How-

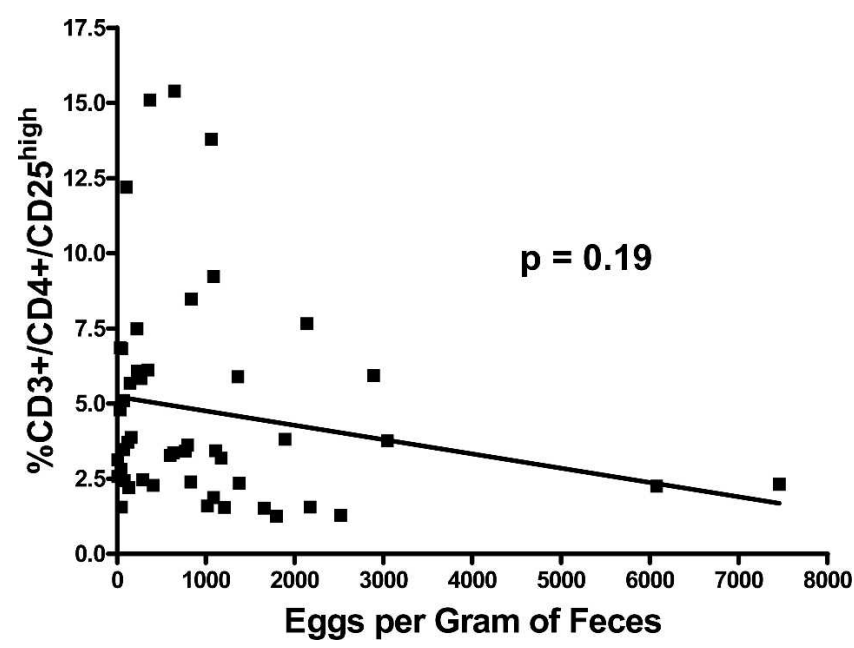

FIGURE 4. No relationship between Treg percentages and infection intensities. Eggs per gram of feces (EPG) of untreated, HIV-1negative patients compared with their percentage of Treg. ever, there are reports that show that Treg can be $\mathrm{CD} 4^{+} \mathrm{CD} 25^{-},{ }^{20,54}$ so our study may not be inclusive of all natural Treg. In fact, in murine schistosome infections, the reliability of CD25 expression as a marker of Treg cell decreased in chronic infections because Foxp3 negative $\mathrm{CD} 4{ }^{+} \mathrm{CD} 25^{+}$cells increased. ${ }^{24}$ Because our study has dealt with adults from a highly endemic area where they are exposed daily to the threat of infection through their occupation, we assume that they have chronic infections. Nevertheless, we realize that the percentage of Treg cells may differ when Treg are defined by measuring FOXP3 positive cells instead of $\mathrm{CD} 25^{\text {high }}$ cells, and acknowledge that as better definitions of human Treg continue to develop, studies should be

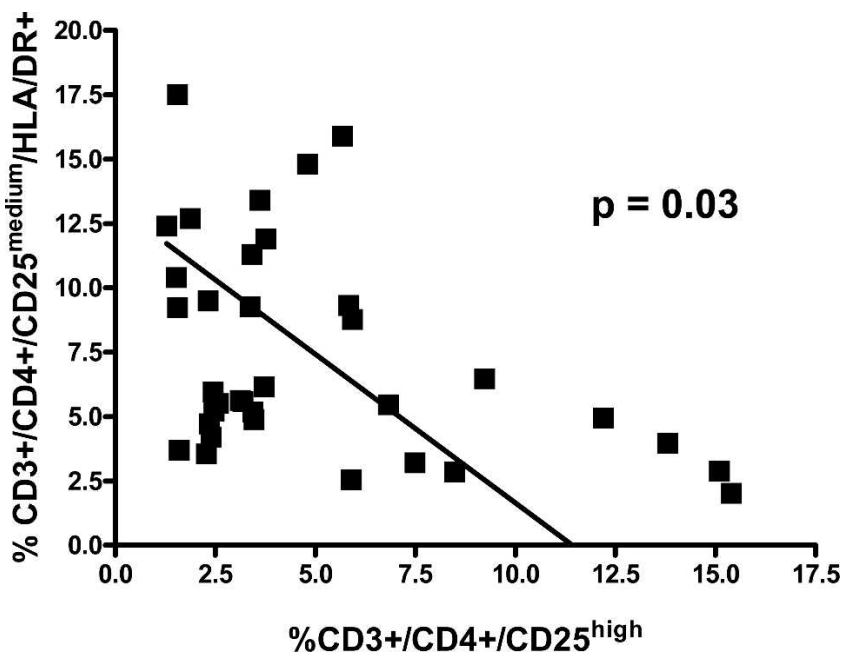

FIGURE 5. Inverse relationship of Treg and activated, putative effector T cells $\left(\mathrm{CD} 4^{+} \mathrm{CD} 25^{\text {medium }} \mathrm{HLA}-\mathrm{DR}^{+}\right.$cells $)$in the peripheral blood of untreated, HIV-1 seronegative, schistosome-infected patients. 
undertaken which incorporate the most complete set of markers available.

This study is the first documentation of cells with a Treg phenotype in human schistosomiasis. The main findings of the study are that some, but not all, actively infected patients exhibit high Treg percentages, and that cured patients exhibit lower proportions of these cells. Furthermore, the percentage of Treg is inversely correlated with the percentage of activated effector CD4 $\mathrm{T}$ cells. In addition, we found that some subsets of Treg were altered upon cure with PZQ. Specifically, lower percentages of Treg expressed the memory (and suppressive) phenotype as indicated by the presence of fewer Treg and fewer of those that expressed CD45RO. Overall, these data indicated that Treg percentages are increased in some people with schistosomiasis mansoni, and when this occurs it can be reversed by treatment and cure. It will be of interest to see whether 1) resistance to re-infection; 2) severe or subtle morbidity; 3 ) humoral immune responses; or 4) cellular immune responses are associated with differences in circulating Treg proportions. These relationships are now being evaluated through ongoing longitudinal studies in larger cohorts of adult men in western Kenya. If any of these relationships exist, it should be possible to determine how treatment and cure alters them, potentially leading to an increase in resistance because of removal of immunoregulation.

\section{Received April 27, 2007. Accepted for publication June 25, 2007.}

Acknowledgments: The authors thank Eric Livaha and all other technical and field staff of the Schistosomiasis Immunology Laboratory (KEMRI) for their professional assistance. This paper is published with the permission of the Director of the Kenya Medical Research Institute. The findings and conclusions in this report are those of the authors and do not necessarily represent the views of the Centers for Disease Control and Prevention.

Financial support: KW was supported in part by the Japan Health Sciences Foundation, CLB was supported by Public Health Service (PHS) Grant T32 AI 060546 from the National Center for Allergy and Infectious Diseases (NIAID) of the National Institutes of Health $(\mathrm{NIH})$ and a training grant from the Ellison Medical Foundation, PNMW was supported by PHS Grant D43 TW007123 from the Fogarty International Center, NIH, and the studies were supported by PHS Grant AI 053695 from the NIAID of the National Institutes of Health, the PHS, Centers for Disease Control and Prevention, and the Kenya Medical Research Institute.

Authors' addresses: Kanji Watanabe, Institute of Tropical Medicine, Nagasaki University (NEKKEN), 1-12-4 Sakamoto, Nagasaki 8528523, Japan, E-mail: watakanj@net.nagasaki-u.ac.jp. Pauline N.M. Mwinzi, Diana M.S. Karanja, and Erick M.O. Muok, Vector Biology and Control Research Centre, Kenya Medical Research Institute, PO Box 1578, Kisumu, Kenya, E-mails: pmwinzi@kisian.mimcom.net, dkaranja@kisian.mimcom.net, and emouk@kisian.mimcom.net. Carla L. Black and Daniel G. Colley, Center for Tropical and Emerging Global Diseases, Room 145 Coverdell Center, University of Georgia, Athens, GA 30602-7399, E-mails: blackc@uga.edu and dcolley@uga.edu. W. Evan Secor, Division of Parasitic Diseases, Centers for Disease Control and Prevention, 4770 Buford Highway, N.E., Mail-stop F-13, Atlanta, GA 30341, E-mail: was4@cdc.gov.

\section{REFERENCES}

1. Ross AG, Bartley PB, Sleigh AC, Olds GR, Li Y, Williams GM, McManus DP, 2002. Schistosomiasis. N Engl J Med 346: 12121220.

2. Gryseels B, Polman K, Clerinx J, Kestens L, 2006. Human schistosomiasis. Lancet 368: 1106-1118.

3. Goddard MJ, Jordan P, 1980. On the longevity of Schistosoma mansoni in man on St. Lucia, West Indies. Trans $R$ Soc Trop Med Hyg 74: 185-191.
4. Butterworth AE, Fulford AJ, Dunne DW, Ouma JH, Sturrock RF, 1988. Longitudinal studies on human schistosomiasis. Philos Trans R Soc Lond B Biol Sci 321: 495-511.

5. Butterworth AE, Curry AJ, Dunne DW, Fulford AJ, Kimani G, Kariuki HC, Klumpp R, Koech D, Mbugua G, Ouma JH, Roberts M, Thiong'o FW, Capron A, Sturrock RF, 1994. Immunity and morbidity in human schistosomiasis mansoni. Trop Geogr Med 46: 197-208.

6. Dunne DW, Butterworth AE, Fulford AJ, Ouma JH, Sturrock RF, 1992. Human IgE responses to Schistosoma mansoni and resistance to re-infection. Mem Inst Oswaldo Cruz 87 (Suppl 4): 99-103.

7. Webster M, Fallon PG, Fulford AJ, Butterworth AE, Ouma JH, Kimani G, Dunne DW, 1997. IgG4 and IgE responses to Schistosoma mansoni adult worms after treatment. J Infect Dis 175: 493-494.

8. Booth M, Shaw MA, Carpenter D, Joseph S, Kabatereine NB, Kariuki HC, Mwatha JK, Jones FM, Vennervald BJ, Ouma JH, Dunne DW, 2006. Carriage of DRB1*13 is associated with increased posttreatment IgE levels against Schistosoma mansoni antigens and lower long-term re-infection levels. J Immunol 176: 7112-7118.

9. Walter K, Fulford AJ, McBeath R, Joseph S, Jones FM, Kariuki HC, Mwatha JK, Kimani G, Kabatereine NB, Vennervald BJ, Ouma JH, Dunne DW, 2006. Increased human IgE induced by killing Schistosoma mansoni in vivo is associated with pretreatment Th2 cytokine responsiveness to worm antigens. J Iтmиnol 177: 5490-5498.

10. Ganley-Leal LM, Mwinzi PN, Cetre-Sossah CB, Andove J, Hightower AW, Karanja DM, Colley DG, Secor WE, 2006. Correlation between eosinophils and protection against re-infection with Schistosoma mansoni and the effect of human immunodeficiency virus type 1 coinfection in humans. Infect Immun 74: 2169-2176.

11. Viana IR, Sher A, Carvalho OS, Massara CL, Eloi-Santos SM, Pearce EJ, Colley DG, Gazzinelli G, Correa-Oliveira R, 1994. Interferon- $\gamma$ production by peripheral blood mononuclear cells from residents of an area endemic for Schistosoma mansoni. Trans $R$ Soc Trop Med Hyg 88: 466-470.

12. Fitzsimmons CM, Joseph S, Jones FM, Reimert CM, Hoffmann KF, Kazibwe F, Kimani G, Mwatha JK, Ouma JH, Tukahebwa EM, Kariuki HC, Vennervald BJ, Kabatereine NB, Dunne DW, 2004. Chemotherapy for schistosomiasis in Ugandan fishermen: treatment can cause a rapid increase in interleukin-5 levels in plasma but decreased levels of eosinophilia and worm-specific immunoglobulin E. Infect Immun 72: 4023-4030.

13. Brown M, Mawa PA, Joseph S, Bukusuba J, Watera C, Whitworth JA, Dunne DW, Elliott AM, 2005. Treatment of Schistosoma mansoni infection increases helminth-specific type 2 cytokine responses and HIV-1 loads in coinfected Ugandan adults. J Infect Dis 191: 1648-1657.

14. Joseph S, Jones FM, Walter K, Fulford AJ, Kimani G, Mwatha JK, Kamau T, Kariuki HC, Kazibwe F, Tukahebwa E, Kabatereine NB, Ouma JH, Vennervald BJ, Dunne DW, 2004. Increases in human T helper 2 cytokine responses to Schistosoma mansoni worm and worm-tegument antigens are induced by treatment with praziquantel. J Infect Dis 190: 835-842.

15. Mutapi F, Burchmore R, Mduluza T, Foucher A, Harcus Y, Nicoll G, Midzi N, Turner CM, Maizels RM, 2005. Praziquantel treatment of individuals exposed to Schistosoma haematobium enhances serological recognition of defined parasite antigens. J Infect Dis 192: 1108-1118.

16. Mduluza T, Ndhlovu PD, Midzi N, Scott JT, Mutapi F, Mary C, Couissinier-Paris P, Turner CM, Chandiwana SK, Woolhouse ME, Dessein AJ, Hagan P, 2003. Contrasting cellular responses in Schistosoma haematobium infected and exposed individuals from areas of high and low transmission in Zimbabwe. Immunol Lett 88: 249-256.

17. Mutapi F, Ndhlovu PD, Hagan P, Spicer JT, Mduluza T, Turner CM, Chandiwana SK, Woolhouse ME, 1998. Chemotherapy accelerates the development of acquired immune responses to Schistosoma haematobium infection. J Infect Dis 178: 289-293.

18. Woolhouse ME, Hagan P, 1999. Seeking the ghost of worms past. Nat Med 5: 1225-1227.

19. Sakaguchi S, Sakaguchi N, Asano M, Itoh M, Toda M, 1995. Immunologic self-tolerance maintained by activated $\mathrm{T}$ cells ex- 
pressing IL-2 receptor alpha-chains (CD25). Breakdown of a single mechanism of self-tolerance causes various autoimmune diseases. J Immunol 155: 1151-1164.

20. Baecher-Allan C, Brown JA, Freeman GJ, Hafler DA, 2001. $\mathrm{CD} 4{ }^{+} \mathrm{CD} 25$ high regulatory cells in human peripheral blood. $J$ Immunol 167: 1245-1253.

21. Jonuleit H, Schmitt E, Stassen M, Tuettenberg A, Knop J, Enk $\mathrm{AH}, 2001$. Identification and functional characterization of human $\mathrm{CD} 4\left(^{+}\right) \mathrm{CD} 25\left(^{+}\right) \mathrm{T}$ cells with regulatory properties isolated from peripheral blood. J Exp Med 193: 1285-1294.

22. Levings MK, Allan S, d'Hennezel E, Piccirillo CA, 2006. Functional dynamics of naturally occurring regulatory $\mathrm{T}$ cells in health and autoimmunity. Adv Immunol 92: 119-155.

23. Cavassani KA, Campanelli AP, Moreira AP, Vancim JO, Vitali LH, Mamede RC, Martinez R, Silva JS, 2006. Systemic and local characterization of regulatory $\mathrm{T}$ cells in a chronic fungal infection in humans. J Immunol 177: 5811-5818.

24. Baumgart M, Tompkins F, Leng J, Hesse M, 2006. Naturally occurring $\mathrm{CD}^{+} \mathrm{Foxp}^{+}{ }^{+}$regulatory $\mathrm{T}$ cells are an essential, IL10 -independent part of the immunoregulatory network in Schistosoma mansoni egg-induced inflammation. J Immunol 176: 5374-5387.

25. Taylor JJ, Mohrs M, Pearce EJ, 2006. Regulatory T cell responses develop in parallel to Th responses and control the magnitude and phenotype of the Th effector population. J Immunol 176: 5839-5847.

26. Singh KP, Gerard HC, Hudson AP, Reddy TR, Boros DL, 2005. Retroviral Foxp3 gene transfer ameliorates liver granuloma pathology in Schistosoma mansoni infected mice. Immunology 114: 410-417.

27. Mwinzi PN, Karanja DM, Colley DG, Orago AS, Secor WE, 2001. Cellular immune responses of schistosomiasis patients are altered by human immunodeficiency virus type 1 coinfection. J Infect Dis 184: 488-496.

28. Karanja DM, Hightower AW, Colley DG, Mwinzi PN, Galil K, Andove J, Secor WE, 2002. Resistance to re-infection with Schistosoma mansoni in occupationally exposed adults and effect of HIV-1 co-infection on susceptibility to schistosomiasis: a longitudinal study. Lancet 360: 592-596.

29. Ganley-Leal LM, Mwinzi PN, Cetre-Sossah CB, Andove J, Hightower AW, Karanja DM, Colley DG, Secor WE, 2006. Higher percentages of circulating mast cell precursors correlate with susceptibility to re-infection with Schistosoma mansoni. Am J Trop Med Hyg 75: 1053-1057.

30. Karanja DM, Colley DG, Nahlen BL, Ouma JH, Secor WE, 1997. Studies on schistosomiasis in western Kenya: I. Evidence for immune-facilitated excretion of schistosome eggs from patients with Schistosoma mansoni and human immunodeficiency virus coinfections. Am J Trop Med Hyg 56: 515521.

31. Bayry J, Triebel F, Kaveri SV, Tough DF, 2007. Human dendritic cells acquire a semimature phenotype and lymph node homing potential through interaction with $\mathrm{CD} 4^{+} \mathrm{CD} 25^{+}$regulatory $\mathrm{T}$ cells. J Immunol 178: 4184-4193.

32. Duggleby RC, Shaw TN, Jarvis LB, Kaur G, Gaston JS, 2007. CD27 expression discriminates between regulatory and nonregulatory cells after expansion of human peripheral blood $\mathrm{CD}^{+} \mathrm{CD}^{2} 5^{+}$cells. Immunology 121: 129-139.

33. Keever-Taylor CA, Browning MB, Johnson BD, Truitt RL, Bredeson CN, Behn B, Tsao A, 2007. Rapamycin enriches for $\mathrm{CD} 4\left(^{+}\right) \mathrm{CD} 25\left(^{+}\right) \mathrm{CD} 27\left(^{+}\right)$Foxp3 $\left({ }^{+}\right)$regulatory $\mathrm{T}$ cells in ex vivo-expanded $\mathrm{CD} 25$-enriched products from healthy donors and patients with multiple sclerosis. Cytotherapy 9: 144-157.

34. Longhi MS, Hussain MJ, Mitry RR, Arora SK, Mieli-Vergani G, Vergani D, Ma Y, 2006. Functional study of $\mathrm{CD} 4^{+} \mathrm{CD} 25^{+}$regulatory $\mathrm{T}$ cells in health and autoimmune hepatitis. J Immunol 176: 4484-4491.

35. Roncador G, Brown PJ, Maestre L, Hue S, MartinezTorrecuadrada JL, Ling KL, Pratap S, Toms C, Fox BC, Cerundolo V, Powrie F, Banham AH, 2005. Analysis of FOXP3 protein expression in human $\mathrm{CD} 4^{+} \mathrm{CD} 25^{+}$regulatory T cells at the single-cell level. Eur J Immunol 35: 1681-1691.

36. Strauss L, Whiteside TL, Knights A, Bergmann C, Knuth A, Zippelius A, 2007. Selective survival of naturally occurring hu- man $\mathrm{CD} 4^{+} \mathrm{CD} 25^{+} \mathrm{Foxp}^{+}$regulatory $\mathrm{T}$ cells cultured with rapamycin. J Immunol 178: 320-329.

37. Valencia X, Yarboro C, Illei G, Lipsky PE, 2007. Deficient $\mathrm{CD} 4{ }^{+} \mathrm{CD} 25$ high $\mathrm{T}$ regulatory cell function in patients with active systemic lupus erythematosus. J Immunol 178: 2579-2588.

38. Roederer M, 2001. Spectral compensation for flow cytometry: visualization artifacts, limitations, and caveats. Cytometry 45 : 194-205.

39. Lühn K, Simmons CP, Moran E, Dung NT, Chau TN, Quyen NT, Thao le TT, Van Ngoc T, Dung NM, Wills B, Farrar J, McMichael AJ, Dong T, Rowland-Jones S, 2007. Increased frequencies of CD4+ CD25(high) regulatory T cells in acute dengue infection. $J$ Exp Med 204: 979-985.

40. Dieckmann D, Plottner H, Berchtold S, Berger T, Schuler G, 2001. Ex vivo isolation and characterization of $\mathrm{CD} 4\left(^{+}\right) \mathrm{CD} 25\left(^{+}\right)$ $\mathrm{T}$ cells with regulatory properties from human blood. $J$ Exp Med 193: 1303-1310.

41. Levings MK, Sangregorio R, Roncarolo MG, 2001. Human $\mathrm{CD} 25\left(^{+}\right) \mathrm{CD} 4\left(^{+}\right)$t regulatory cells suppress naive and memory $\mathrm{T}$ cell proliferation and can be expanded in vitro without loss of function. J Exp Med 193: 1295-1302.

42. Ko HS, Fu SM, Winchester RJ, Yu DT, Kunkel HG, 1979. Ia determinants on stimulated human T lymphocytes. Occurrence on mitogen- and antigen-activated T cells. J Exp Med 150: 246-255.

43. Eggena MP, Barugahare B, Jones N, Okello M, Mutalya S, Kityo C, Mugyenyi $\mathrm{P}$, Cao H, 2005. Depletion of regulatory T cells in HIV infection is associated with immune activation. J Immunol 174: 4407-4414.

44. Butterworth AE, David JR, Franks D, Mahmoud AA, David PH, Sturrock RF, Houba V, 1977. Antibody-dependent eosinophilmediated damage to 51Cr-labeled schistosomula of Schistosoma mansoni: damage by purified eosinophils. J Exp Med 145: $136-150$.

45. Yazdanbakhsh M, Tai PC, Spry CJ, Gleich GJ, Roos D, 1987. Synergism between eosinophil cationic protein and oxygen metabolites in killing of schistosomula of Schistosoma mansoni. J Immunol 138: 3443-3447.

46. Sakaguchi S, 2005. Naturally arising Foxp3-expressing $\mathrm{CD} 25^{+} \mathrm{CD} 4^{+}$regulatory $\mathrm{T}$ cells in immunological tolerance to self and non-self. Nat Immunol 6: 345-352.

47. Nishimura H, Honjo T, 2001. PD-1: an inhibitory immunoreceptor involved in peripheral tolerance. Trends Immunol 22: 265268.

48. Blattman JN, Greenberg PD, 2006. PD-1 blockade: rescue from a near-death experience. Nat Immunol 7: 227-228.

49. Barber DL, Wherry EJ, Masopust D, Zhu B, Allison JP, Sharpe AH, Freeman GJ, Ahmed R, 2006. Restoring function in exhausted CD8 T cells during chronic viral infection. Nature 439: 682-687.

50. Day CL, Kaufmann DE, Kiepiela P, Brown JA, Moodley ES, Reddy S, Mackey EW, Miller JD, Leslie AJ, DePierres C, Mncube Z, Duraiswamy J, Zhu B, Eichbaum Q, Altfeld M, Wherry EJ, Coovadia HM, Goulder PJ, Klenerman P, Ahmed R, Freeman GJ, Walker BD, 2006. PD-1 expression on HIVspecific $\mathrm{T}$ cells is associated with T-cell exhaustion and disease progression. Nature 443: 350-354.

51. Muhlbauer M, Fleck M, Schutz C, Weiss T, Froh M, Blank C, Scholmerich J, Hellerbrand C, 2006. PD-L1 is induced in hepatocytes by viral infection and by interferon- $\alpha$ and $-\gamma$ and mediates T cell apoptosis. J Hepatol 45: 520-528.

52. Smith P, Walsh CM, Mangan NE, Fallon RE, Sayers JR, McKenzie AN, Fallon PG, 2004. Schistosoma mansoni worms induce anergy of $\mathrm{T}$ cells via selective up-regulation of programmed death ligand 1 on macrophages. J Immunol 173: 1240-1248.

53. Colley DG, Sasser LE, Reed AM, 2005. PD-L2 ${ }^{+}$dendritic cells and $\mathrm{PD}-1^{+} \mathrm{CD}^{+} \mathrm{T}$ cells in schistosomiasis correlate with morbidity. Parasite Immunol 27: 45-53.

54. Yagi H, Nomura T, Nakamura K, Yamazaki S, Kitawaki T, Hori S, Maeda M, Onodera M, Uchiyama T, Fujii S, Sakaguchi S, 2004. Crucial role of FOXP3 in the development and function of human $\mathrm{CD}_{2} 5^{+} \mathrm{CD} 4^{+}$regulatory $\mathrm{T}$ cells. Int Immunol 16 : $1643-1656$. 